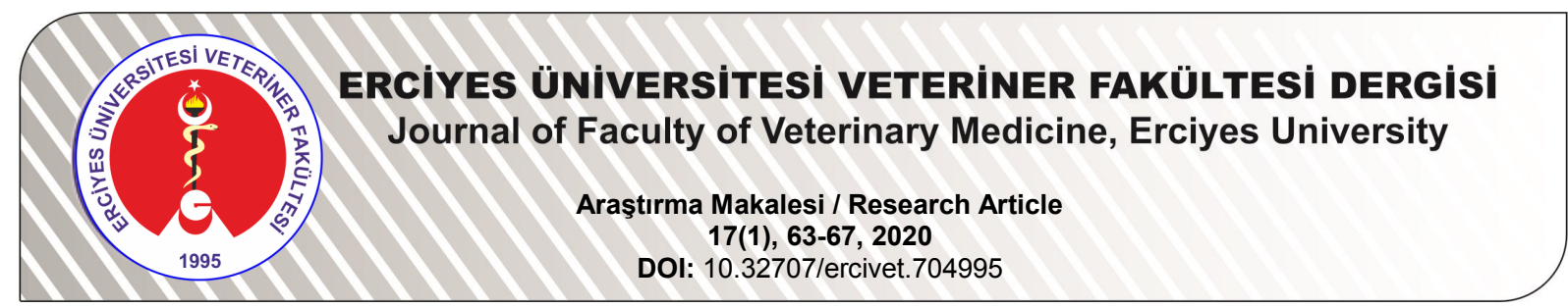

The Investigation of Serum Estrogen, Progesterone, AMH and IGF-1 Profiles in Lactating and Non Lactating Mares after Altrenogest Administrations*

\author{
İbrahim Mert POLAT ${ }^{1}$, Ömer KORKMAZ², Taha Burak ELIFOĞLU ${ }^{1}$, İlknur Pir YAĞCl ${ }^{1}$, \\ Hatice Esra ÇOLAKOĞLU ${ }^{3}$, Mert PEKCAN ${ }^{4}$
}

\footnotetext{
${ }^{1}$ Department of Obstetrics and Gynecology, Faculty of Veterinary Medicine, Kırıkkale University, Kırıkkale-TURKEY ${ }^{2}$ Department of Obstetrics and Gynecology, Faculty of Veterinary Medicine, Harran University, Harran, Şanlıurfa-TURKEY

${ }^{3}$ Department of Obstetrics and Gynecology, Faculty of Veterinary Medicine, Ankara University, Ankara- TURKEY ${ }^{4}$ Department of Biochemistry, Faculty of Veterinary Medicine, Ankara University, Ankara-TURKEY
}

Corresponding author: İbrahim Mert POLAT; e-mail: vethekmert@gmail.com ORCID: 0000-0003-4029-1247 How to cite: Polat IM, Korkmaz O, Elifoğlu TB, Yağcı IP, Çolakoğlu HE, Pekcan M.The Investigation of Serum Estrogen, Progesterone, AMH and IGF-1 Profiles in Lactating and Non Lactating Mares after Altrenogest Administrations. Erciyes Üniv Vet Fak Derg 2020;17(1): 63-67.

Summary: The objective of this study is to follow up the follicular growth in ovaries until mating by ultrasonography to determine of pregnancy rates, serum estrogen, progesterone, AMH and IGF-1 concentrations in mares which synchronized with altrenogest and to compare the obtained data with non-lactating mares. The study was carried out during breeding season while ovaries were active; lactating mares were included in Group $1(n=8)$ and non-lactating mares in Group $2(\mathrm{n}=8)$. In both groups, synchronization was performed by administration of altrenogest (Regumate $\left.{ }^{\circledR}\right)$ and prostaglandin F 2 alpha (PGF2 $\alpha$ ). Dominant follicle diameters of non-lactating mares were found to be greater than those of lactating ones. During the study, estrogen, progesterone, AMH and IGF-1 levels were significantly lower in the lactating mares. The non- lactating mares were found to have a first pregnancy conception rate $(75 \%)$, similar to that of lactating mares $(62 \%)\left(x^{2}=1.54, P=0.62\right)$. It was concluded that in the mares synchronized with altrenogest, the presence of lactation and the foal are significantly influences ovarian activities, ovarian steroid levels, AMH and IGF-1 levels. Therefore, in order to increase pregnancy rates in lactating mare, sexual cycle synchronization with altrenogest are considered to be a suitable method.

Key words: Altrenogest, anti müllerian, estrogen, lactation, mare, progesterone

\title{
Laktasyonda Olan ve Laktasyonda OImayan Kısraklarda Altrenogest Uygulaması Sonrası Serum Östrojen, Progesteron, AMH ve IGF-1 Düzeylerinin Araştırılması
}

Özet: Sunulan çalışmanın amacı, altrenogest ile senkronize edilen laktasyondaki kısraklarda aşım zamanına kadar geçen süreçte ovaryumlardaki folliküler gelişimlerin ultrasonografi ile takibi, serum östrojen, progesteron, AMH ve IGF1 konsantrasyonlarının ölçülmesi ve gebelik oranlarının değerlendirilerek bu verilerin laktasyonda olmayan kısraklarla karşılaştırılmasıdır. Çalışma, üreme sezonun başladığı ve ovaryumların aktif olduğu üreme sezonunda gerçekleştirildi; laktasyonda olan kısraklar Grup 1'e (n=8) ve laktasyonda olmayan kısraklar Grup 2'ye $(n=8)$ dahil edildi Her iki gruba altrenogest (Regumate ${ }^{\circledR}$ ) ve prostaglandin F2a ile senkronizasyon gerçekleştirildi. Laktasyonda olmayan kısrakların dominant follikül çapları laktasyonda olanlara göre daha büyük bulundu. Çalışma süresince toplanan kan örneklerinde östrojen, progesteron, AMH ve IGF-1 düzeyleri laktasyondaki kısraklarda belirgin olarak düşük bulundu. Laktasyonda olmayan kısrakların ilk aşımda gebe kalma oranı (\%75), laktasyonda olan kısraklarla (\%62.5) benzer bulundu $\left(x^{2}=1.54\right.$, $P=0.62$ ). Altronogest ile senkronize edilen kısraklarda laktasyonun ve tayın varlığının ovaryum faaliyetlerine, ovaryum steroid düzeylerine, AMH ve IGF-1 düzeylerine önemli oranda etki ettiği kanısına varıldı. Bu nedenle laktasyonda olan kısraklarda gebelik oranlarını artırmak amacıyla altrenogest ile seksüel siklus senkronizasyonunun uygun bir yöntem olduğu düşünüldü.

Anahtar kelimeler: Altrenogest, anti-müllerian, kısrak, laktasyon, östrojen, progesteron

\section{Introduction}

Estrus cycles of mares are controlled by the hormones which respond to photoperiod of season in mares. The photoreceptors of the retina turns light stimulus into signals and transfers these signals to

Geliş Tarihi/Submission Date : 18.02 .2020

Kabul Tarihi/Accepted Date : 17.03.2020

*This study is supported by Kirikkale University, Scientific Research Projects Coordination Unit grant 2016/012 superior cervical ganglion which have adrenergic neuronal endings that reach the pineal gland and have action in different pathways of synthesis of melatonin. Thus, the increased exposure to photoperiod results in a decrease of melatonin secretion. As a result of decrease in melatonin secretion, gonadotropin releasing hormone $(\mathrm{GnRH})$ is stimulated. The $\mathrm{GnRH}$ has a decent role in hypothalamic-pituitary axis and is transferred to adenohypophysis where it stimulates follicle stimulating hormone (FSH) and luteinizing hormone $(\mathrm{LH})$ responsible of follicle growth 
and ovulation (Satue and Gardon, 2013). Lactating mares have a completely different reproductive metabolism from those of cyclic mares (Heidler et al., 2003). At early lactation, alteration of Growth Hormone (GH), Insulin-like Growth Factor 1 (IGF-1) and leptin have some roles in metabolism to regulate various mechanisms. These changes are beneficial to energy metabolism, apart from suppressing reproductive activity (Block et al., 2001). These hormonal alterations are most effective at early lactation right after delivery and their influence go down by time (Heidler et al., 2003). While $\mathrm{GH}$ is responsible for growth and development, it also mediates secretion of IGF-1 from liver and stimulates ovarian activity (Izadyar et al., 1998). Thus GH directly or with the help of IGF-1, in gonadotropin dependent or independent ways affects ovarian steroidogenesis (Hull and Harvey, 2000). Heidler et al. (2003) found that $\mathrm{GH}$ levels were lower in non-lactating mares than in lactating ones. However, researchers could not find any statistically meaningful difference in $\mathrm{GH}$ levels in cows at lactation than those in non-lactation period (Block et al., 2001). Estrogen is one of the determinative factors on IGF-1 levels and it elevates secretion of IGF-1. Also, estrogen augments number of $\mathrm{GH}$ receptors, so IGF-1 becomes more bio-effective (Ginther et al., 2002). The granulosa cells of preantral and small antral follicles secrete anti-mullerian hormone (AMH) (Ball et al 2008) and plasma concentration of $\mathrm{AMH}$ was found to be positively correlated with the number of follicles having a diameter of 6-20 $\mathrm{mm}$ in mares (Claes et al., 2014). AMH is secreted in minimal concentrations from follicles with a diameter greater than $30 \mathrm{~mm}$ (Ball et al., 2008) and its plasma concentration increases while follicles are developing (Vernunft et al., 2011). Although serum AMH concentrations may show individual variations among mares, these concentrations reportedly do not vary with the different stages of the estrous cycle or pregnancy (Ball et al., 2008; Almeida et al., 2011). Though many studies have shown the relationship between $\mathrm{AMH}$ and fertility, further studies are required to reveal the effects of lactation on AMH profile. The aim of this study is to monitor follicular growth in ovaries till mating and to investigate estrogen, progesterone, $\mathrm{AMH}$, IGF-1 levels and pregnancy rates in mares which are synchronized with altrenogest, and to compare them with non-lactating mares which synchronized with altrenogest.

\section{Material and Methods}

\section{Animals and study groups}

The study was approved by Kırıkkale University Local Ethics Committee for Animal Experiments with the approval number 15/06. Sixteen mares with ages ranging between 4-10 years, a body condition score of at least 7 , having given birth at least once, without any genital system infections, and with regular estrus cycles were used. This study was carried out during breeding season while ovaries were active. The mares that lactate and were housed with their foals were included in group $1(n=8)$, non-lactating mares were included in group $2(n=8)$. Immediately before the study, USG examinations were performed, the mares with inactive ovaries or uterus pathologies were not included in the study. In this research, no artificial lighting, feed additive, hormone or drugs were used to stimulate ovarian activity

\section{Ultrasonographic examinations}

Ovaries and uterine horns were ultasonographically examined daily with Pie Medical-Falco 100 device. Both uterine horns and ovarian follicle diameters were recorded. Examination of uterine horns with USG was performed using a linear transducer at the site of near corpus uteri via dorsal-ventral. Including both endometrial and stratum vascular layers, the distances between top and bottom serosal layers were measured as uterine horn diameter. Pregnancy examinations were performed with USG after mating at days 15,35 and 60 .

\section{Drug administrations}

For synchronization of estrus cycles; $0.044 \mathrm{mg} / \mathrm{kg}$ altrenogest (Regumate) administered orally daily for 12 days. At the $12^{\text {th }}$ day of altrenogest administration, single dose of $12.5 \mathrm{mcg}$ PGF2 $\alpha$ was administered intramuscularly.

\section{Collection of blood samples and biochemical analyses}

Blood samples were collected to plain vacuumed tubes from jugular vein right before drug administrations. Blood samples centrifuged at $3500 \mathrm{rpm}$ for 15 minutes and stored at $-20^{\circ} \mathrm{C}$ until analyses. Blood sera estrogen (Genway $\AA)$, progesterone (Cayman $®)$, AMH (Beckman $®)$ and IGF-1 (IDS $®)$ levels were measured with commercial ELISA kits and ELISA MAT-2000 microplate reader.

\section{Statistical analyses}

All the statistical analyses were performed using SPSS version 14.1. First, descriptive analyses of the parameters (mean and standard error) according to the experimental conditions were done. Then, the evaluation of normality by the Kolmogorov Smirnov test was performed. As all data were considered as nonparametric, Mann Whitney test was carried out. Statistical significance was considered when $\mathrm{P}<0.05$.

\section{Results}

During the study, follicle sizes of both groups have been measured daily. In both study groups, generally dominant follicle used to develop at right ovary. It is 
Table 1 Mean values for estradiol, progesterone, IGF-I and AMH serum concentrations of lactating and non-lactating mares

\begin{tabular}{|c|c|c|c|c|c|c|c|c|}
\hline \multirow{3}{*}{$\begin{array}{c}\text { Days of } \\
\text { Sam- } \\
\text { pling }\end{array}$} & \multicolumn{8}{|c|}{$\begin{array}{c}\text { Parameter } \\
(\overline{\mathrm{x}} \pm \mathrm{S} \overline{\mathrm{x}})\end{array}$} \\
\hline & \multicolumn{2}{|c|}{$\begin{array}{c}E_{2} \\
(p g / m L)\end{array}$} & \multicolumn{2}{|c|}{$\begin{array}{c}P_{4} \\
\text { (ng/mL) }\end{array}$} & \multicolumn{2}{|c|}{$\begin{array}{c}\text { IGF-I } \\
\text { (ng/mL) }\end{array}$} & \multicolumn{2}{|c|}{$\begin{array}{c}\text { AMH } \\
\text { (ng/mL) }\end{array}$} \\
\hline & LM & NLM & LM & NLM & LM & NLM & LM & NLM \\
\hline \multirow[t]{2}{*}{0} & $7.6 \pm 0.87$ & $\begin{array}{c}8.72 \pm 1.4 \\
3\end{array}$ & $\begin{array}{c}1.14 \pm 0.1 \\
8\end{array}$ & $\begin{array}{c}2.80 \pm 0.4 \\
3\end{array}$ & $\begin{array}{c}27.3 \pm 1.9 \\
6\end{array}$ & $\begin{array}{c}48.7 \pm 4.1 \\
2\end{array}$ & $\begin{array}{c}0.32^{\mathrm{a}} \pm 0.1 \\
2\end{array}$ & $\begin{array}{c}0.77^{\mathrm{b}} \pm 0.0 \\
9\end{array}$ \\
\hline & \multicolumn{2}{|c|}{$\mathrm{P}=0.08$} & \multicolumn{2}{|c|}{$P=0.06$} & \multicolumn{2}{|c|}{$P=0.15$} & \multicolumn{2}{|c|}{$\mathrm{P}=0.05$} \\
\hline \multirow[t]{2}{*}{$3^{\text {rd }}$} & $\begin{array}{c}11.84 \pm 1 \\
02\end{array}$ & $\begin{array}{c}10.78 \pm 0 \\
72\end{array}$ & $\begin{array}{c}2.23 \\
\pm 0.30\end{array}$ & $\begin{array}{c}2.98 \pm 1.1 \\
2\end{array}$ & $\begin{array}{c}28.60^{\mathrm{a}} \pm 2 \\
26\end{array}$ & $\begin{array}{c}54.86^{\mathrm{b}} \pm 3 \\
59\end{array}$ & $\begin{array}{c}0.36^{\mathrm{a}} \pm 0.2 \\
0\end{array}$ & $\begin{array}{c}0.62^{b} \pm 0.0 \\
6\end{array}$ \\
\hline & \multicolumn{2}{|c|}{$P=0.07$} & \multicolumn{2}{|c|}{$P=0.09$} & \multicolumn{2}{|c|}{$P=0.03$} & \multicolumn{2}{|c|}{$P=0.02$} \\
\hline \multirow[t]{2}{*}{$6^{\text {th }}$} & $\begin{array}{c}22.32 \pm \\
2.37\end{array}$ & $\begin{array}{c}26.45 \pm 2 \\
65\end{array}$ & $\begin{array}{l}3.82^{\mathrm{a}} \\
\pm 0.12\end{array}$ & $\begin{array}{c}7.52^{\mathrm{b}} \pm 1.4 \\
1\end{array}$ & $\begin{array}{c}32.80^{\mathrm{a}} \pm 2 \\
70\end{array}$ & $\begin{array}{c}62.24^{b} \pm 5 \\
21\end{array}$ & $\begin{array}{c}0.47^{\mathrm{a}} \pm 0.1 \\
2\end{array}$ & $\begin{array}{c}0.84^{b} \pm 0.1 \\
2\end{array}$ \\
\hline & \multicolumn{2}{|c|}{$P=0.13$} & \multicolumn{2}{|c|}{$P=0.02$} & \multicolumn{2}{|c|}{$P=0.03$} & \multicolumn{2}{|c|}{$P=0.02$} \\
\hline \multirow[t]{2}{*}{$12^{\text {th }}$} & $\begin{array}{l}42.60 \\
\pm 2.26\end{array}$ & $\begin{array}{l}36.71 \\
\pm 1.34\end{array}$ & $\begin{array}{c}11.40^{\mathrm{a}} \pm 1 \\
12\end{array}$ & $\begin{array}{c}16.40^{\mathrm{b}} \pm 1 \\
52\end{array}$ & $\begin{array}{c}75.70^{\mathrm{a}} \pm 4 \\
21\end{array}$ & $\begin{array}{c}88.77^{\mathrm{b}} \pm 6 \\
34\end{array}$ & $\begin{array}{c}1.30^{b} \pm 0.4 \\
5\end{array}$ & $\begin{array}{c}1.11^{\mathrm{c}} \pm 0.2 \\
3\end{array}$ \\
\hline & \multicolumn{2}{|c|}{$P=0.16$} & \multicolumn{2}{|c|}{$P=0.026$} & \multicolumn{2}{|c|}{$P=0.05$} & \multicolumn{2}{|c|}{$P=0.012$} \\
\hline \multirow[t]{2}{*}{ OD } & $\begin{array}{c}64.62^{\mathrm{a}} \pm 2 \\
27\end{array}$ & $\begin{array}{c}84.30^{\mathrm{b}} \pm 1 \\
67\end{array}$ & $\begin{array}{c}0.32 \pm 0.1 \\
1\end{array}$ & $\begin{array}{c}0.48 \pm 0.0 \\
3\end{array}$ & $\begin{array}{c}108.50^{b} \pm \\
6.70\end{array}$ & $\begin{array}{c}148.50^{\mathrm{C}} \pm \\
7.65\end{array}$ & $\begin{array}{c}0.56^{\mathrm{a}} \pm 0.2 \\
8\end{array}$ & $\begin{array}{c}0.77^{b} \pm 0.2 \\
7\end{array}$ \\
\hline & \multicolumn{2}{|c|}{$P=0.04$} & \multicolumn{2}{|c|}{$P=0.25$} & \multicolumn{2}{|c|}{$P=0.002$} & \multicolumn{2}{|c|}{$P=0.041$} \\
\hline
\end{tabular}

LM: Lactating mares NLM: nonlactating mares. E2: Estradiol, P4: Progesterone, IGF-I: Insuline Like Growth Factor-I, AMH: Anti-mullerian hormone, OD: Day of ovulation

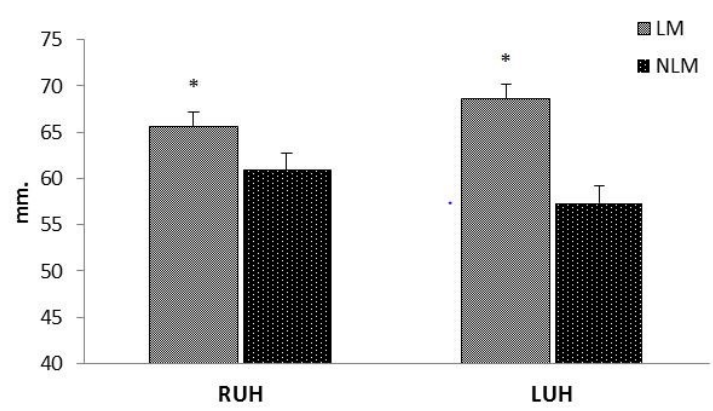

Figure 1. Mean diameters (standard error mean) of uterine horns during study period. RUH: Right uterine horn LUH: Left uterine horn. LM: Lactating mares NLM: Nonlactating mares. $(* P<0.05)$

found that, in lactating mares, dominant follicle sizes that ovulated are bigger than in non-lactating mares. It is observed that dominant follicle development used to take place on average 12-13 days after last drug treatment in both groups. Average dominant follicle diameter which will ovulate in lactating mares is measured as $43.2 \pm 0.82 \mathrm{~mm}$ and $52.6 \pm 0.63 \mathrm{~mm}$ in non-lactating mares $(P<0,05)$. Even though ovarian activity was monitored with ultrasonography, the clinical signs of estrus in lactating mares were observed to be weaker than in non-lactating mares. The sizes of uterine horns in both groups have been shown in Figure 1.

In lactating mares, the diameter of right uterine horn
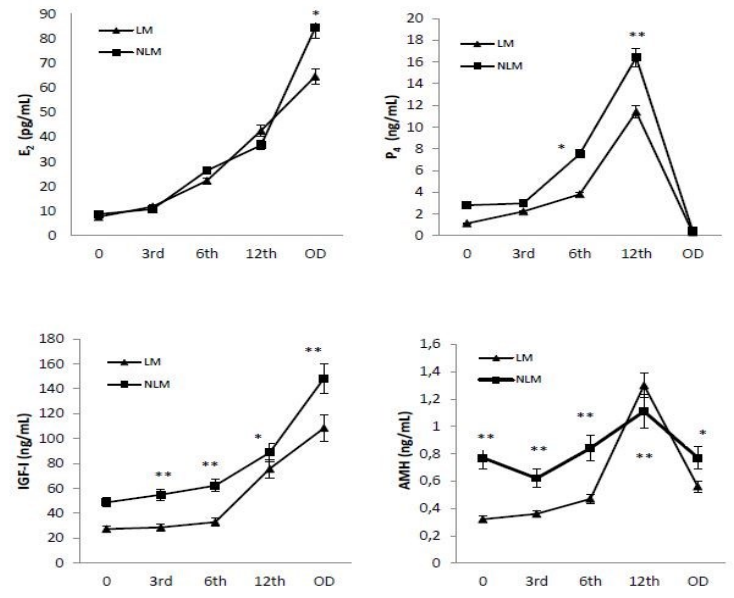

Figure 2. Mean values of estradiol, progesterone, IGF-I and AMH serum concentrations from day 0 to ovulation day of mares $\left({ }^{*} \mathrm{P}<0.05\right.$, $\left.{ }^{* *} \mathrm{P}<0.01\right)$. LM: Lactating mares $\mathbf{N L M}$ : nonlactationg mares. $\mathbf{E}_{2}$ : Estradiol, $\mathbf{P}_{4}$ : Progesterone, IGF-I: Insuline Like Growth Factor-I, AMH: Antimüllerian hormone. OD: Day of ovulation.

was observed to be bigger than in non-lactating ones. The results of blood serum analyses have presented in Figure 2 and Table 1.

Serum estradiol levels of lactating mares were observed to be lower than in non-lactating group. Moreover, though in both groups serum IGF-1 levels had sharp rises on ovulation day, a decrease was observed in serum AMH levels after selection of dominant follicle. 
In the initial pregnancy diagnosis, similar pregnancy rates have been observed in both groups ( 5 at lactating mares, 6 at non lactating ones). One mare showed estrus signs at day 22 after coitus. USG examination showed that embryonic loss had occurred. Serum estradiol levels were found to be lower in lactating mares than non-lactating mares. The reason for this was thought to be that the dominant follicle diameters were smaller than the ones not in lactation.

\section{Discussion and Conclusion}

Maximum follicle sizes of ovaries could be $5 \mathrm{~mm}$ smaller in miniature breeds like pony and could be 10 $\mathrm{mm}$ bigger in giant breeds like Friesian. Also, in spring season, follicle size could be $5-8 \mathrm{~mm}$ bigger than in summer season (Brinsko et al., 2010). Moreover, A study by Koyla et al. (2000) reported that lactation had no effect on maximum follicle diameter in their research on five mares from two different breeds in a breeding season. In contrast to Koyla et al. (2000), the maximum follicle diameters differed between the groups in this study. Perkins and Grimmet (2001) reported that pregnancy rates in lactating and non-lactating mares (67\% vs. $66 \%$ ) were similar. In this study, similar pregnancy rates (6 in non-lactating mares and 5 in lactation) were obtained in both groups in the first pregnancy examination (day 15) after mating. One mare in lactation displayed estrus again on the $22^{\text {nd }}$ day after mating. Ultrasonographic examination revealed an embryonic death. This finding was found to be similar to the one from the study by Van Niekerk and van Niekerk (1998a), which revealed a higher incidence of embryonic death in lactating mares. The primary source of progesterone is corpora lutea which is required for embryo-uterine interactions (embryo mobility and implantation) and uterine secretions. The progesterone levels were found lower in lactating mares (van Niekerk and van Niekerk, 1998b). It was thought that it may be a factor that may increase the risk of embryonic death in early pregnancy period. Plasma concentrations of progesterone gradually increased during altrenogest treatment from days 1 to 8 and rapidly decreased after the administration of prostaglandin (Korosua et al., 2012). In our study, similar to the study by Korosua et al. (2012), progesterone profiles rapidly increased on the $3^{\text {rd }}$ days of altrenogest administrations. However, these increase were similar in both groups, the response of nonlactating mares was higher than lactating ones. Collins et al. (2014) compare the time of altrenogest therapy in Przewalski's mares. After altrenogest administrations for 12 days, estrogen and progesterone responses were higher than in a 14-day therapy.

Preantral and small antral follicles secrete AMH and the concentrations are positively correlated with the number of follicles and also $8 \mathrm{~mm}$ or larger follicles (Claes et al., 2014). AMH is secreted at low levels by follicles with a diameter greater than $30 \mathrm{~mm}$ and its plasma concentration increases with the number of developing follicles. Although serum AMH concentrations may show individual variations among mares, these concentrations reportedly do not vary with the different stages of the estrous cycle, pregnancy and lactation period. In this study AMH levels were found significantly lower than in non-lactating mares. Whether these findings can be extrapolated to mares still remains to be determined. Further studies are required to determine $\mathrm{AMH}$ course during the whole lactation period. In addition, at $6^{\text {th }}$ day of altrenogest treatment, $\mathrm{AMH}$ levels were rising in the same way in both groups when ovarian follicles reached $20-30 \mathrm{~mm}$ diameter. Even if $\mathrm{AMH}$ is low in lactating mares, it can be increased under the effects of progesterone treatment. Dominant follicles have higher IGF-1 levels than the largest subordinated follicles which are positively correlated with estradiol levels in mares. The increase in the IGF-1 concentration in the future dominant follicle reflects the follicle to decrease $\mathrm{FSH}$ sensitivity and increase LH availability. The other follicles in the follicular wave possess the same capacity for dominance but never reach similar sizes and the largest follicle alone continues developing, until it becomes dominant and ovulates (Salazar-Ortiz et al., 2014). IGF-1 has been shown to enhance FSH -induced granulose cell differentiation, particularly LH receptor acquisition which is critical for adequate gonadotropin output because, prolactin can negatively regulate the $\mathrm{LH}$ response to $\mathrm{GnRH}$ especially in the presence of dopamine (Hodson et al., 2010). In a study in mare ovarian cell culture; prolactin stimulated cells were influenced from the $\mathrm{GnRH}$ response. Thus, in our study; the presence of lactation also prolactin and oxytocin can affect the maximum follicle diameter, negatively.

As a result, it is concluded that in mares which were synchronized with altrenogest, lactation and presence of foal have considerably effect on ovarian activity; especially on diameter of dominant follicle, ovarian steroids, levels of AMH and IGF-1. For this reason, it was thought that in order to increase pregnancy rates in lactating mares sexual cycle synchronization with altrenogest could be appropriate method. Furthermore, it was confirmed that altrenogest, in combination with PGF2a, has tremendous potential for optimizing the fertility in lactating mares.

\section{Acknowledgments}

This study is supported by Kirikkale University, Scientific Research Projects Coordination Unit grant 2016/012.

\section{Conflict of Interest}

The authors declare that the research was conducted in the absence of any commercial or financial rela- 
tionships that could be construed as a potential conflict of interest.

\section{REFERENCES}

Almeida J, Ball BA, Conley AJ, Place NJ, Liu IKM, Scholtz EL, Mathewson L, Stanley SD, Moeller BC. Biological and clinical significance of anti-Mullerian hormone determination in blood serum of the mare. Theriogenology 2011; 76(8); 1393-403.

Ball BA, Conley AJ, MacLaughlin DT, Grundy SA, Sabuer K, Liu IKM. Expression of anti-Müllerian hormone $(\mathrm{AMH})$ in equine granulosa-cell tumors and in normal equine ovaries. Theriogenology 2008; 70: 968-977.

Block SS, Butler RW, Ehrhardt RA, Bell AW, Van Amburgh ME, Boisclair YR. Decreased concentration of plasma leptin in periparturient dairy cows is caused by negative energy balance. $J$ Endocrinol 2001; 171: 339-48.

Brinsko SP, Blanchard TL, Varner DD, Schumacher J, Love CC, Hinrichs K, Hartman D. Manual of Equine Reproduction. Third Edition. Mosby Elsevier, 2010; pp. 124-8.

Claes A, Ball BA, Scoggin KE, Esteller-Vico A, Kalmar JJ, Conley AJ, Squires EL, Troedsson $\mathrm{MH}$. The interrelationship between anti-Müllerian hormone, ovarian follicular populations and age in mares. Equine Vet J 2014; 47: 537-41.

Collins CW, Monfort SL, Vick MM, Wolfe BA, Weiss $\mathrm{RB}$, Keefer CL, Songsasen N. Oral and injectable synthetic progestagens effectively manipulate the estrous cycle in the Przewalski's horse (Equus ferus przewalskii). Animal Reproduction Science 2014; 148(1-2): 42-52.

Ginther OJ, Beg MA, Bergfelt DR, Kot K. Activin A, estradiol, and free insulin-like growth factor I in follicular fluid preceding the experimental assumption of follicle dominance in cattle. Biol Reprod 2002; 67: 14-9.

Heidler B, Parvizi N, Sauerwein H, Bruckmaier RM, Heintges U, Aurich JE, Aurich C. Effects of lactation on metabolic and reproductive hormones in Lipizzaner mares. Domest Anim Endocrinol 2003; 25: 47-59

Hodson DJ, Townsend J, Gregory SJ, Walters C, Tortonese DJ. Role of prolactin in the gonadotroph responsiveness to gonadotrophin releasing hormone during the equine annual reproductive cycle. J Neuroendocrinol 2010; 22(6): 509-17.

Hull KL, Harvey S. Growth hormone: a reproductive endocrine-paracrine regulator? Rev Reprod 2000; 5: $175-82$.
Izadyar F, Hage WJ, Colenbrander B, Bevers MM. The promotory effect of growth hormone on the developmental competence of in vitro-matured bovine oocytes is due to improved cytoplasmic maturation. Mol Reprod Develop 1998; 49: 444-53.

Korosue K, Murase H, Sato F, Ishimaru M, Harada T, Watanabe G, Taya K, Nambo Y. Successful induction of lactation in a barren Thoroughbred mare: growth of a foal raised on induced lactation and the corresponding maternal hormone profiles. J Vet Med Sci 2012; 74(8): 995-1002.

Koyla GR, Sheryt SK, Lynn GN. Follicular growth and estradiol concentrations in foaling and nonparturient mares. J Equine Vet Sci 2000; 20(4): 266-8.

Perkins NR, Grimmett JB. Pregnancy and twinning rate in thoroughbred mares following the administration of human chorionic gonadotropine (hCG). N Z Vet J 2001; 49: 94-100.

Salazar-Ortiz J, Monget P, Guillaume D. The influence of nutrition on the insulin-like growth factor system and the concentrations of growth hormone, glucose, insulin, gonadotropins and progesterone in ovarian follicular fluid and plasma from adult female horses (Equus caballus). Reprod Biol Endocrinol 2014; 12(1): 72.

Satue K, Gardon KJ. A Review of the estrous cycle and the neuroendocrine mechanisms in the mare. J Steroids Horm Sci 2013; 115(4): 1-8.

Van Niekerk $\mathrm{CH}$, Van Niekerk FE. The effect of dietary protein on reproduction in the mare. VII. Embryonic development, early embryonic death, foetal losses and their relationship with serum progestagen. J S Afr Vet Med Assoc 1998a; 69: 150-5.

Van Niekerk FE, Van Niekerk $\mathrm{CH}$. The effect of dietary protein on reproduction in the mare. VI. Serum progestagen concentrations during pregnancy. J S Afr Vet Assoc 1998b; 69: 143-9.

Vernunft A, Schneider F, Tuchscherer A, Becker F, Kanitz W. AntiMüller-Hormon (AMH) kann zur vorhersage des follikelwachstums bei stuten dienen. Pferdeheilkunde 2011; 27(3): 293-6. 
